\title{
Present status of citrus leprosis in Argentina and Paraguay
}

\author{
Sara Cáceres ${ }^{1}$, Alcides Aguirre ${ }^{1}$, Norma Costa ${ }^{2}$, Olga de Coll ${ }^{3}$, Luis Gonzáles Segnana ${ }^{4}$, Nelson Fariña ${ }^{5}$, \\ Aline D. Tassi' ${ }^{6}$, Renata F. Calegario ${ }^{6}$, Gilberto J. de Moraes ${ }^{7}$, Juliana Freitas-Astúa ${ }^{8,9}$, Juliana A. Pereira ${ }^{9}$, \\ Renato B. Salaroli ${ }^{6} \&$ Elliot W. Kitajima ${ }^{6}$
}

${ }^{1}$ Estación Experimental Agropecuaria (EEA) Bella Vista, Instituto Nacional de Tecnología Agropecuaria (INTA), C. Correo 5, 3432 Bella Vista, Corrientes, Argentina; ${ }^{2}$ EEA Concordia, INTA, CC 34, 3200 Concordia, Entre Ríos, Argentina; ${ }^{3}$ EEA Montecarlo, INTA, CC 4, 3384 Montecarlo, Misiones, Argentina; ${ }^{4}$ Departamento de Biología, Facultad de Ciencias Agrarias, Universidad Nacional de Asunción, San Lorenzo, Paraguay; ${ }^{5}$ Servicio Nacional de Sanidad y Calidad Vegetal (SENAVE), Asunción, Paraguay; ${ }^{6}$ Departamento de Fitopatologia e Nematologia, ${ }^{7}$ Departamento de Entomologia e Acarologia, Escola Superior de Agricultura Luiz de Queiroz, Universidade de São Paulo, Cx. Postal 9, 13418-900, Piracicaba, SP, Brazil; ${ }^{8}$ Embrapa Mandioca e Fruticultura, Cx. Postal 7, 44380-000, Cruz das Almas, BA, Brazil; ${ }^{9}$ Centro APTA Citros Sylvio Moreira, Cx. Postal 4, 13560-970, Cordeirópolis, SP, Brazil

Author for correspondence: Elliot W. Kitajima, e-mail: ewkitaji@esalq.usp.br

\begin{abstract}
Citrus leprosis (CL) was first described in South America in the 1920's. It is considered similar to a disease first observed back to 1860 in Florida. It is a destructive disease characterized by localized lesions on the leaves, fruits and stems, which may lead to the death of the affected plant if left untreated. Around 1940, CL was demonstrated to be transmitted by Brevipalpus mites in Argentina. Because little information exists on the status of CL pathosystem in Argentina and Paraguay, a survey was made in several citrus growing areas of these countries from 2009 to 2011, to evaluate its presence and relevance as well as the identification of the virus and the mite vector. CL was found in most of the sweet orange and/or mandarin orchards in Paraguay (Departamentos de Boquerón, Concepción, San Pedro, Cordillera, Alto Paraná, Itapúa) and Argentina (Provincias de Misiones, Corrientes, Entre Ríos). Incidence was usually low. The causal virus was identified as Citrus leprosis virus $C(\mathrm{CiLV}-\mathrm{C})$ by RT-PCR, electron microscopy and immunofluorescence. In all the visited regions in Paraguay and the region of Montecarlo, Argentina, the mites collected in plants infected by CiLV-C were identified as $B$. phoenicis.
\end{abstract}

Key words: Brevipalpus phoenicis, B. obovatus, CiLV-C.

\section{INTRODUCTION}

CiLV-C is a serious problem for the Brazilian citrus industry, particularly in the state of São Paulo, the world largest orange juice producer. Leprosis is not causing serious losses due to an intense use of chemical acaricides to control the mite vector at a cost of US\$ 80 million/ year. This promoted the development of a strong research programs by a consortium of Brazilian and foreign research institutes, with the aim to reduce such a high production cost, which resulted in significant advance on the knowledge of the CL pathosystem (Rodrigues et al., 2003; Bastianel et al., 2010).

A destructive disease of sweet orange characterized by bark lesions and spotted fruits, the first observation of which may date back to 1860, was described in Florida, and referred to as "scaly bark" or "nail head rust" (Fawcett, 1911). According to Knorr \& DuCharme (1951) this disease was first observed in Pinellas county in 1860, and it spread to several parts of the state but it has not been registered after 1960's (Childers et al., 2003). A similar disease was reported in the 1920's in Argentina and Paraguay, known locally as "lepra explosiva" (Spegazzini, 1920; Zeman,
1932) and in Brazil where it was coined "variola" by Bitancourt (1934). A comparison of the symptoms led to the conclusion that this citrus disease in Florida and South America was the same and the name leprosis was established (Knorr \& DuCharme, 1951). Frezzi (1940) and Vergani (1945) in Argentina demonstrated that the mite Tenuipalpus pseudocuneatus (= Brevipalpus obovatus Donnadieu) (Acari: Tenuipalpidae) was involved in the dissemination of leprosis. The causal agent of leprosis was controversial, ranging from fungal etiology to reaction to a mite toxin, but gradually, the evidences pointed out that the disease is of viral nature (Knorr, 1968; Kitajima et al., 1972; Colariccio et al., 1995; Rodrigues et al., 2003). It was also found that leprosis symptoms may be caused by two distinct viruses based on the cytopathic effects (Kitajima et al., 2003; Rodrigues et al., 2003), both transmitted by Brevipalpus mites: the rare nuclear type (Citrus leprosis virus N-CiLV-N), a likely member of the Dichorhabdovirus genus, whose type member is Orchid fleck virus (OFV) (Kondo et al., 2006); and the prevalent and more aggressive cytoplasmic type Citrus leprosis virus $C$ (CiLV-C). Its genome was entirely sequenced (Locali-Fabris et al., 2006; Pascon et al., 2006) and it was accepted as the type-member 
of the new genus Cilevirus (Locali-Fabris et al., 2006; Carstens, 2010; Locali-Fabris et al., 2012), resulting in molecular (Locali et al., 2003) and immunochemical tools (Calegario et al., 2013) for CiLV-C detection. Although symptoms in the fruits and barks caused by CiLV-C and CiLV-N are undistinguishable, there is a slight but consistent difference in leaf symptoms: CiLV-N causes smaller lesions with a dark central spot surrounded by a bright yellow halo while lesions caused by CiLV-C may reach larger size and present a light green color commonly with one or more gummy rings (Bastianel et al., 2010). Analyses made on photographic records and samples of herbarium from sweet orange leaves from Florida strongly suggest that leprosis in that State was caused by CiLV-N (Kitajima et al., 2011a). So far CiLV-N has been found in some parts of Brazil, north of Panama (Rodrigues et al., 2003; Bastianel et al., 2010) and recently in Tolimán, state of Querétaro, Mexico (Gabriel Otero-Colina, personal communication). Ultrastructural, molecular and transmission studies suggest that mite vector/virus relationship in CiLV-C pathosystem is of circulative type (Kitajima et al., 2008). All sweet orange (Citrus sinesnsis [L.] Osbeck) varieties are highly susceptible to CiLV-C, while mandarins (C. reticulate Blanco) and grapefruit (C. paradisi Macf.) are moderately susceptible, and lemons (C. limon L.) practically immune (Bastianel et al., 2010). For a long time CiLV-C was thought to be restricted to Citrus spp., but cases of natural infection of other plant species by CiLV-C were recently observed. In Colombia, Swinglea glutinosa Blanco, a Rutaceae plant commonly used as hedge around sweet orange orchards, was found infected by CiLV-C, showing chlorotic spots (León et al., 2008). In Brazil, Commelina benghalensis L. plants growing below the canopy of CiLV-C infected sweet orange were infested by B. phoenicis Geijskes and showed necrotic lesions as a consequence of infection by CiLV-C (Nunes et al., 2012a). On the other hand, experimental infection by mechanical transmission of CiLV-C was obtained in Chenopodium quinoa Willd., C. amaranticolor Coste \& Reyn. and Gomphrena globosa L. (Colariccio et al., 1995). More recently, several plant species were shown to be hosts of CiLV-C after experimental transmission by viruliferous $B$. phoenicis such as Hibiscus rosa-sinensis L., Malvaviscus arboreus Cav., Grevilea robusta A. Cunn., Bixa orellana L., Arabidopsis thaliana (L.) Heynh., and others (Kubo et al., 2010; Garita-Salazar et al., 2011; Nunes et al., 2012b). An important finding was that the common bean (Phaseolus vulgaris L.) is an excellent indicator plant for CiLV-C, responding with localized necrotic lesions to mite inoculation, in less than five days (Groot et al., 2006; Tassi et al., 2009), in contrast to 4-6 weeks in sweet orange.

CiLV-C is formally registered in Bolivia, Colombia and Venezuela besides Argentina, Brazil and Paraguay. In 2000 it was found in Panama (Dominguez et al., 2001) and in less than five years reached Southern Mexico (SanchezAnguiano, 2005; Izquierdo et al., 2011), threatening all the citrus industry of the Caribbean region and the USA.
In Paraguay, sweet orange plants are cultivated usually in small farms, in the Departament of Itapúa, Alto Paraná, Cordillera and Boquerón, totaling ca. 12,000 ha (Figure 1). The production is entirely intended to the internal market either as fresh fruit or for processed juice production. Most orchards belong to small farmers, but there are two large enterprises, respectively Frutika, at Kressburgo, Dept. Itapúa and Estancia Estrella, at Mbaracayú, Dept. of Alto Paraná.

The first reference to leprosis in South America was made by Spegazzini (1920) in a publication about citrus diseases referring to the disease as "lepra explosiva" in the surroundings of Asunción, the capital city. According to Bitancourt (1955) it is possible that the symptoms described by Spagazzini (1920), large bark lesions without quoting leaf or fruit lesions, better apply to psorosis. However, further surveys, made by Fawcett \& Bitancourt in 1937 (1940) at Asunción and suburbs as Trinidad and San Lorenzo, confirmed the presence of leprosis in Paraguay, and reported that it appeared to be more serious than in the USA or Brazil. Gonzáles-Segnana et al. (1997) surveyed most of the citrus growing areas in the mid 1990's to evaluate the distribution of Citrus tristeza virus (CTV) in Paraguay and observed that leprosis was present in most of the inspected sweet orange orchards. Until recently few actions have been made to control CL because of the limited economical importance of sweet oranges in the country. However, the growth of the internal consumption and demands of the international market may result in a significant increase in the planted area, since soil, topography and climatic condition permit citrus production throughout the country. Under such situation, control of CL may become an important issue.

Argentine citrus output (yield of 2,559,418 ton from 134,800 ha in 2010) is the 7th in the world after China, Brazil, USA, Mexico, Spain and Italy. There are two main production areas: the northwest, which grows lemons, and the northeast, with mandarins, grapefruits and sweet oranges (see Figure 2 A). In 2010, the northeast region (provinces of Misiones, Corrientes, Entre Ríos and north of Buenos Aires) produced 1,094,748 t, occupying 75,535 ha, $42.77 \%$ of the total yield and $56 \%$ of the citrus planted area in Argentina (Federcitrus, 2011).

Leprosis was probably first described in Argentina by Zeman (1932) who reported some foci in the province of Corrientes (1921), Entre Ríos (1922), and also in the islands of the Delta (1925). He associated correctly bark symptoms to the leaf and fruit lesions. Later the disease was found in other provinces as Misiones, Chaco, Formosa and Santa Fe. Survey made in 1937 by Fawcett and Bitancourt (Fawcett, 1937; Fawcett and Bitancourt, 1940), found leprosis in the provinces of Misiones and Corrientes, but not to the South of Monte Caseros, including Uruguay. Pioneer works on leprosis in Argentina started at the Laboratorio de Fitopatología at Bella Vista. Frezzi (1940) found that affected plants once pruned and sprayed with sulphur recovered well, and did not succeed in transmitting 
the disease by grafting, suggesting that the symptoms could result from toxins injected by the mites. Vergani (1945) at Concordia reproduced the results of Frezzi and could not transmit the disease by mechanical inoculation endorsing the toxaemia theory of Frezzi as did Marchionato (1950) later.

Currently CL is present in Misiones affecting sweet orange and in few mandarins orchards, but because only a few orange plants is grown, the disease is not important in this region (Olga de Coll, unpublished results). On the other hand, in the province of Corrientes, the main growing area of sweet orange (Bella Vista, Saladas, Concepción and Monte Caseros), leprosis is endemic and causes concern. CL is also present in Entre Ríos (Chajarí and Concordia) affecting sweet oranges. Management of CL based on eradication or pruning of the affected trees followed by spraying of chemical acaricides has been effective as proposed by the Instituto Nacional de Tecnología Agropecuaria (INTA). Curiously, no official report of CL in Uruguay exists, although only the river Uruguay separates the leprosis affected orchards in the province of Entre Ríos and the citrus production area at Salto, Uruguay. The vector, Brevipalpus mites, has been detected throughout the citrus growing areas but $\mathrm{CL}$ is not present in the northest region of Argentina, and in the region of San Pedro, North of Buenos Aires (García, 1996; Vaccaro \& Mousqués, 1996; Segade \& Mitidieri, personal communication).

Because the province of Corrientes is the most important sweet orange producer in Argentina, CL is a major concern and additional details are given in Cáceres \& Aguirre (2009). Most (72\%) of the sweet orange produced in the province are of late-season type, mainly Valencia; $22 \%$ are early-season varieties (Hamlin, Westin, Navel, etc.), and $6 \%$, mid-season varieties (Criolla and Salustiana). CL has been registered on Valencia, Valencia Seedless, Hamlin, Bahianinha, Lane Late, Newhall, Navelate, Navelina, Domasia, Alargada, Pixie and also in mandarins and hybrids (Clemenules, Ortanique, Namco). Complete CL symptoms (leaves, fruits and stems) are observed in Valencia and Hamlin sweet oranges while in mandarins, symptoms are mainly on the leaves, rarely on the fruits (Cáceres \& Aguirre, 2009). Similar observation was made by Bastianel et al. (2008), when assessing the response of mandarins and hybrids to leprosis in Brazil. Symptoms on mandarins at Corrientes seem to be milder than those observed at the province of Misiones. Lack of appropriate management, due to economical or climatic factors, results in the intensification of CL. Noticeable leprosis symptoms start in the fall and continue throughout the winter. Percentage of fruits infested by Brevipalpus mites, either with or without leprosis symptoms was about the same (5.5\%) in July, 1990 (Cáceres \& Aguirre, 2009).

Information on the situation of leprosis in Argentina and Paraguay remained fragmentary since its original discovery. To better understand the situation of the leprosis in these countries, a joint survey was organized involving
Argentine and Paraguayan researchers with the participation of specialists from Brazil, from 2009 to 2012. This article reports the results of these surveys updating the status of leprosis in Paraguay and Argentina.

\section{MATERIAL AND METHODS}

Seven field trips were made in these four years, covering nine citrus growing areas in Paraguay and eight in Argentina, From all visited places (Table 1; Figures 1, 2), whenever plants exhibiting leprosis symptoms were found, samples were collected (leaves, twigs and fruits, when present) from five or six plants, considered representative of different parts of the orchard. Samples were processed in Paraguay at the laboratory of the Departamento de Biología, Facultad de Ciencias Agrarias, Universidad Nacional de Asunción, San Lorenzo. Samples collected in Argentina were processed at the laboratory of the Estación Experimental Agropecuaria de Bella Vista (EEA INTA Bella Vista) or de Concordia (EEA INTA Concordia). The processing included selection of leaves with symptoms and separation of Brevipalpus mites. Small pieces of the lesions were fixed in a buffered mixture of glutaraldehyde and paraformaldehyde and taken to the Núcleo de Microscopia Eletrônica (NAP/MEPA) at the Escola Superior de Agricultura Luiz de Queiroz, of the Universidade de São Paulo.

Samples were fixed only with aldehyde, dehydrated in ethanol and embedded in acrylic LRWhite resins for immunofluorescence (Maunsbach \& Afzelius, 1999). Semi-thin sections (1-1.5 $\mu \mathrm{m})$ were treated successively with bovine serum albumin blocking solution, anti-p29 (putative nucleocapsidal protein) of CiLV-C (Calegario et al., 2013), anti-rabbit IgG conjugated with fluorescein, and examined with a Zeiss Axioskop light microscope equipped with UV illumination (Kikkert et al., 1997). Some leaves with symptoms were dried and used for RT-PCR assays, using primers specific for CiLV-C (Locali et al., 2003) to confirm the presence of CiLV-C at the Centro APTA Citros Sylvio Moreira, Cordeirópolis, SP, Brazil. Collected mites were fixed in $70 \%$ ethanol and processed for light (LM) and scanning electron microscopic (SEM) examinations, which were made respectively at the Acarology laboratory and NAP/MEPA at ESALQ/USP. For LM, mites were mounted on Hoyer's medium while for SEM, mites were dehydrated and mounted on double coated carbon tape placed on top of aluminum stubs and examined in a LEO 435VP scanning electron microscope.

\section{RESULTS AND DISCUSSION}

\section{Surveys in Paraguay}

Departamento de Boquerón: The visited orchards were located in the municipalities of Filadelfia and Neuland (Figure 1, points $1 \& 2$ ), a region which is known as Chaco. 
TABLE 1 - Localities in Paraguay and Argentina where citrus leprosis symptoms were detected on citrus (sweet orange, mandarin) and the results of detection assays for CiLV-C (RT-PCR, transmission electron microscopy-TEM) on collected samples and identification of sampled Brevipalpus mites

\begin{tabular}{|c|c|c|c|c|}
\hline Localities & coordinates & Mites* & RT-PCR** & TEM*** \\
\hline \multicolumn{5}{|l|}{ Paraguay } \\
\hline \multicolumn{5}{|l|}{ Dept. Boquerón } \\
\hline \multirow[t]{2}{*}{ Filadelphia } & $\mathrm{S} 22^{\circ} 17^{\prime} 327$ & $B p^{1}$ & $4 / 4^{3}$ & $5 / 10^{4}$ \\
\hline & $\mathrm{W} 59^{\circ} 58^{\prime} 832$ & & & \\
\hline \multirow[t]{2}{*}{ Neuland } & $\mathrm{S} 22^{\circ} 38^{\prime} 371$ & $B p$ & $7 / 7$ & $4 / 7$ \\
\hline & $\mathrm{W} 60^{\circ} 06^{\prime} 549$ & & & \\
\hline \multicolumn{5}{|l|}{ Dept. Concepción } \\
\hline \multirow[t]{2}{*}{ Belén, Esc.Agrotécnica, Aldea SOS } & $\mathrm{S} 23^{\circ} 22^{\prime} 528$ & $B p$ & $1 / 1$ & $1 / 1$ \\
\hline & $\mathrm{W} 57^{\circ} 14^{\prime} 124$ & & & \\
\hline \multirow[t]{2}{*}{ Concepción, Esc.Agrotécnica } & S $23^{\circ} 22^{\prime} 789$ & $B p$ & $0 / 1$ & $1 / 1$ \\
\hline & W57º $14^{\prime} 109$ & & & \\
\hline \multicolumn{5}{|l|}{ Dept. Cordillera } \\
\hline \multirow[t]{2}{*}{ Caapcupé, Inst.Agron.Nac. } & S $25^{\circ} 19^{\prime} 094$ & -2 & $1 / 1$ & $1 / 1$ \\
\hline & W57º9’481 & & & \\
\hline \multicolumn{5}{|l|}{ Dept. Alto Paraná } \\
\hline \multirow[t]{2}{*}{ Mbaracayú } & $\mathrm{S} 25^{\circ} 00^{\prime} 568$ & - & $3 / 3$ & $1 / 3$ \\
\hline & W54ㄴㅇ' 131 & & & \\
\hline \multicolumn{5}{|l|}{ Dept. Itapúa } \\
\hline \multirow{2}{*}{ Kressburgo, Frutika } & S $26^{\circ} 201664$ & $B p$ & $1 / 1$ & $1 / 2$ \\
\hline & W $55^{\circ} 03^{\prime} 425$ & & & \\
\hline \multirow[t]{2}{*}{ Carlos Antonio López, Esc.Agrotecnica } & $\mathrm{S} 26^{\circ} 19^{\prime} 070$ & $B p$ & $3 / 3$ & $1 / 2$ \\
\hline & W $55^{\circ} 02^{\prime} 096$ & & & \\
\hline \multirow[t]{2}{*}{ Major Antonio Otaño } & $\mathrm{S} 26^{\circ} 51^{\prime} 545$ & $B p$ & $0 / 1$ & $1 / 2$ \\
\hline & W $54^{\circ} 42^{\prime} 835$ & & & \\
\hline \multicolumn{5}{|l|}{ Argentina } \\
\hline \multicolumn{5}{|l|}{ Prov. Misiones } \\
\hline \multirow[t]{2}{*}{ Montecarlo, EEA Montecarlo } & $\mathrm{S} 26^{\circ} 34^{\prime} 250$ & $B p$ & $2 / 4$ & $2 / 4$ \\
\hline & W 54ํำ'959 & & & \\
\hline \multirow[t]{2}{*}{ Montecarlo, Colonia Luján } & S $26^{\circ} 40^{\prime} 973$ & $B p$ & $1 / 2$ & $1 / 2$ \\
\hline & W $54^{\circ} 54^{\prime} 234$ & & & \\
\hline \multirow[t]{2}{*}{ Ruiz de Montoya } & S $27^{\circ} 00^{\prime} 070$ & $B p$ & $1 / 3$ & $1 / 3$ \\
\hline & W $55^{\circ} 02^{\prime} 710$ & & & \\
\hline \multicolumn{5}{|l|}{ Prov. Corrientes } \\
\hline \multirow[t]{2}{*}{ Bella Vista Colonia 3 de Abril } & S $28^{\circ} 26^{\prime} 200$ & $B p, B o, \mathrm{a}$ & $2 / 3$ & $1 / 3$ \\
\hline & W $58^{\circ} 57^{\prime} 730$ & & & \\
\hline \multirow[t]{2}{*}{ Bella Vista EEABV } & S $28^{\circ} 27^{\prime} 014$ & $B p, B o, \mathrm{a}$ & $3 / 4$ & $2 / 4$ \\
\hline & W $58^{\circ} 58^{\circ} 818$ & & & \\
\hline \multirow[t]{2}{*}{ Monte Caseros } & $\mathrm{S} 30^{\circ} 15^{\prime} 500$ & - & $1 / 1$ & $1 / 1$ \\
\hline & $\mathrm{W} 57^{\circ} 45^{\prime} 100$ & & & \\
\hline Prov. Entre Ríos & & & & \\
\hline Chajarí, Colonia La Libertad & S $30^{\circ} 47^{\prime} 600$ & - & $1 / 2$ & $2 / 2$ \\
\hline & $\mathrm{W} 58^{\circ} 05^{\prime} 100$ & & $1 / 2$ & $2 / 2$ \\
\hline Concordia, EEA Concordia & S $31^{\circ} 24^{\prime} 700$ & $B p, B o, \mathrm{a}$ & $1 / 3$ & $2 / 3$ \\
\hline & $\mathrm{W} 58^{\circ} 06^{\prime} 500$ & & & \\
\hline
\end{tabular}

*Identification made by light and scanning electron microscopy.at ESALQ/USP, Piracicaba, SP, Brazil

** RT-PCR assays carried out on dried leaves at Centro APTA Citros, Cordeiropolis, SP, Brazil.

*** Transmission electron microscopy made on leaf tissues where samples were collected. They were processed and examined at ESALQ/USP. The numbers refers to the positive cases of detection of CiLV-C in the total of examined samples.

${ }^{1}$ Bp-Brevipalpus phoenicis; Bo- B. obovatus; a- asymmetric mites (see text)

${ }^{2}$ Mites not collected.

${ }^{3}$ Number of positive cases/total samples analyzed by RT-PCR

${ }^{4}$ Idem, by transmission electron microscopy

It is a dry region with average $400 \mathrm{~mm}$ of rain/year. Citrus plants were introduced from Texas at the beginning of the colonization and few introductions were made thereafter. Cultivated citrus plants are mandarin, grapefruit, lemon,
Mexican lime, sour and sweet orange mostly in small scale, in backyards. Sweet oranges were usually ungrafted and of unknown varieties. Most of the area in that region is dominated by pastures and isolated from other citrus 


\section{S. Cáceres et al.}

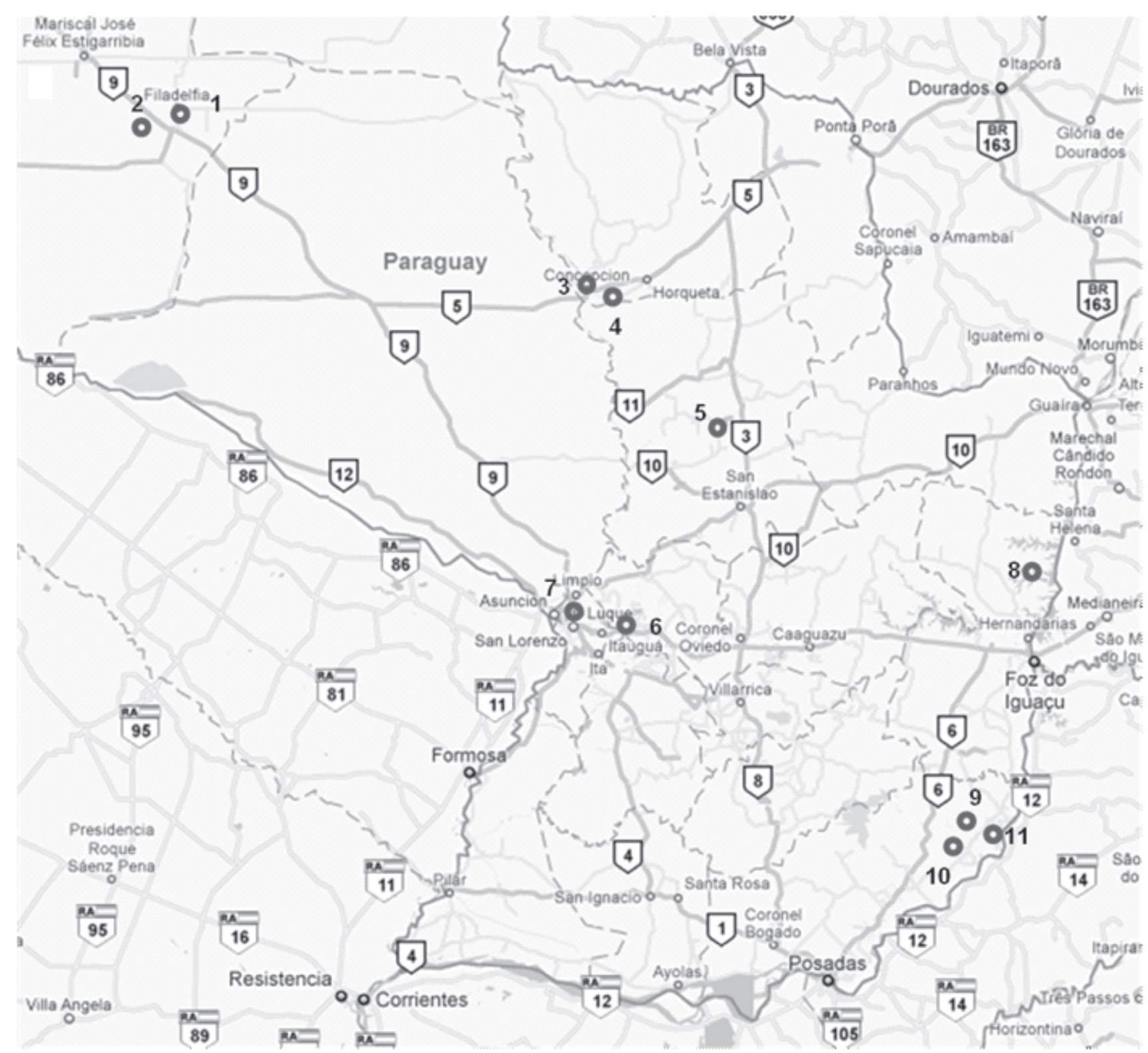

FIGURE 1 - Map of Paraguay showing localities surveyed for citrus leprosis indicated by circles. A. Departamento (Dept.) de Boquerón: 1. Filadelfia; 2. Neuland; B. Dept. de Concepción: 3. Concepción; 4. Belén; C. Dept. de San Pedro: 5. Choré; D. Dept. Cordillera: 6. Caacupé; E. Distrito Capital: 7. San Lorenzo; F. Dept. Alto Paraná: 8. Mbaracayú; G. Dept. Itapúa: 9. Kressburgo; 10. Carlos Antonio López; 11. Mayor Otaño.

growing areas by more than $300 \mathrm{~km}$. A survey on the occurrence of Citrus tristeza virus (CTV) in Paraguay (Gonzáles-Segnana et al., 1997) revealed that this is the only region in Paraguay where CTV is absent, possibly due to unfavorable conditions for the aphid vector Toxoptera citricida Kirk., the distance from other citrus growing areas and lack of introduction of citrus plants from other regions. However, leprosis was endemic in all the sweet oranges found (Figure 3A) and Brevipalpus mites were present in these trees.
Departamento de Concepción: Citrus is a marginal crop in this Departamento, thus inspections were made on citrus orchards belonging to two Escuelas Agrícolas (secondary degree school devoted to prepare technicians for agribusiness): one private, at Belén (Figure 1, point 4), near the capital city of Concepción, sustained by an international organization (Aldea SOS). Small plantations of sweet orange (Valencia) were found with low incidence of leprosis symptoms (leaves, fruits and stems). The other, federal, at Concepción (Figure 1, 


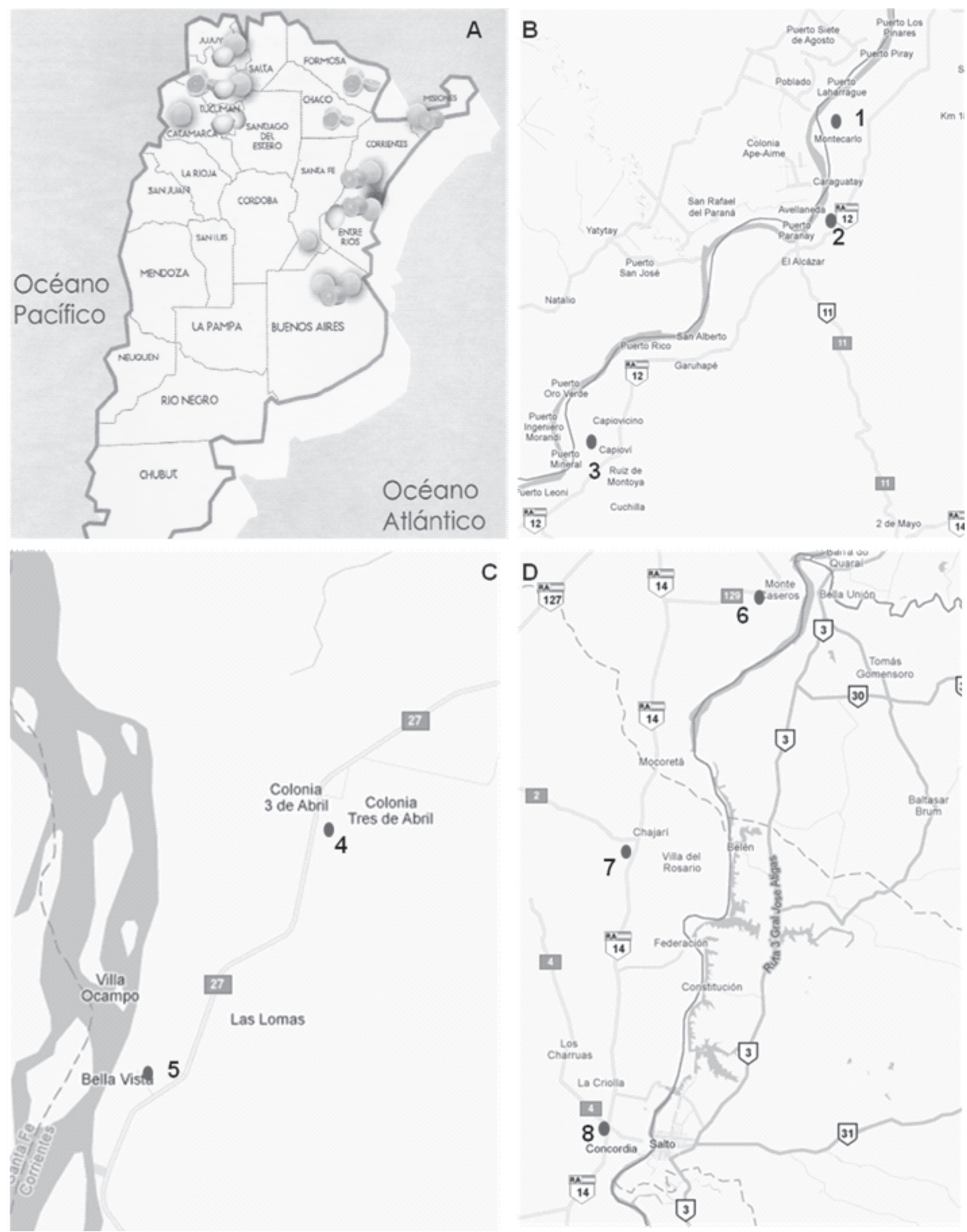

FIGURE 2 - A. Map of Argentina showing the main citrus growing areas and the products (lemon, mandarin, grapefruit and sweet oranges). B-D. Maps of distinct provinces of Argentina with indications of the visited sites; B. Province of Misiones: 1. Montecarlo; 2. Colonia Luján; 3. Ruiz de Montoya; C. Province of Corrientes: 4. Colonia 3 de Abril; 5. Bella Vista; D. Provinces of Corrientes and Entre Ríos: 6. Monte Caseros; 7. Chajarí; 8. Concordia.

point 3) also had small collection of different citrus types including sweet orange. In the latter, a low incidence of leprosis symptoms was noticed. Brevipalpus mites were present and collected.
Departamento de San Pedro: Here there are also few commercial orchards, and the only one visited was an experimental collection of citrus types at the Estación Experimental de Choré (Figure 1, point 5). There were few 
sweet orange plants and all of them had leprosis symptoms. No samples was collected.

Distrito Capital (Asunción and surroundings): Fawcett and Bitancourt (1940), during their trip to Paraguay in 1937, only visited orchards in Asunción and suburbs, where they described many citrus diseases including leprosis. Now, practically there are no commercial orchards at Distrito Capital due to the intense urbanization and the only organized plantation of citrus is an experimental collection kept at the Facultad de Ciencias Agrarias, Universidad Nacional de Asunción, at San Lorenzo (Figure 1, point 7), by one of the authors (LGS), where no leprosis is present.

Departamento de Cordillera: Just south to Asunción, this region has little activity on citrus growing. Inspections were made on a small citrus collection at the Instituto Agronómico Nacional (IAN) at Caacupé (Figure 1, point 6). There were few citrus varieties, among them 'Valencia' sweet orange, which showed leaf and stem lesions of leprosis. Also in a small commercial plantation of 'Valencia' sweet orange, next to IAN few plants with symptoms of leprosis were found. No mites were collected.

Departamento de Alto Paraná: Mbaracayú (Figure 1, point 8) has the second largest citrus plantation (300 ha) of Paraguay, managed by the company Estancia Estrella. Sweet orange, lemons, mandarins and grapefruits are grown. Low incidence of leprosis was observed on some parcels of sweet orange ('Valencia', 'Salustiana', 'Folha Murcha') (Figure 3B). No mites were collected.

Departamento de Itapuá: This is the main citrus growing area in Paraguay. Frutika (Kimex Group), is established at Kressburgo (District of Carlos Antonio López) (Figure 1, point 9). It is the largest citrus grower in Paraguay (ca. 1,800 ha), producing several citrus types including sweet orange, for fresh internal market (70\%) and juice (30\%) for export. The company keeps a strict management for several diseases and pests, including leprosis. It also receives the production of small growers nearby. Only recently Frutika experienced the presence of leprosis in some parcels, probably introduced through contaminated fruits of the suppliers, but it is now under control. Only few leprosisinfected plants were observed in an abandoned orchard of 'Valencia' sweet orange. Two more locations were inspected in this Departamento: Escuela Agrícola, Federal, at Carlos Antonio López (Figure 1, point 10), a collection of several citrus types is maintained for teaching purposes, including some sweet orange- 'Valencia' and 'Criolla', a local variety. Few plants in both orchards were found showing leprosis symptoms, on the leaves, fruits and stems (Figure 3C). In Major Otaño (Figure 1, point 11), two small private 'Valencia' sweet orange orchards were visited, and in both a low incidence of leprosis was observed. Brevipalpus mites were found infesting the leprosis-affected sweet orange plants, and sampled for further exams.

\section{Surveys in Argentina}

Provincia de Misiones: There are many small citrus growers, producing mostly mandarins, in this region Inspections were made on the experimental field of the Estación Experimental Agropecuaria (EEA) de Montecarlo, INTA (Figure 2B, point 1). Leprosis symptoms were observed on few 'Clemenules' mandarins and 'Valencia' sweet oranges. Inspection of two commercial orchards at Colonia Luján (Figure 1D), South to Montecarlo (Figure 2B, point 2) gave similar results. In another private orchard, leprosis symptoms were found on 'Folha murcha' sweet orange. A small commercial plantation of 'Valencia' sweet orange, in a private orchard at the municipality of Ruiz de Montoya (Figure 2B, point 3), had a light incidence of leprosis. Similar observation was made in another abandoned orchard of 'Valencia' sweet orange. In the backyard of the Hotel Helvecia at Montecarlo, there were few seedlings of sweet orange of unknown variety, which showed leprosis symptoms. From all the plants showing leprosis symptoms, Brevipalpus mites were sampled.

Provincia de Corrientes: Several medium sized (5-6 ha) commercial orchards of sweet orange, mostly cv. 'Valencia', were visited at Colonia 3 de Abril (Figure 2C, point 4), about $15 \mathrm{~km}$ north of Bella Vista, and in all of them leprosis was present on sweet oranges with low incidence. At the EEA Bella Vista (EEABV) (Figure 2C, point 5), most of the experimental citrus orchards are chemically treated and leprosis-free, but some parcels of cvs. 'Hamlin' and 'Valencia' were left untreated for experimental purposes. Leprosis was present there and it was severe, provoking intense leaf and fruit drop. In the District of Santa Rosa, a visit was made to the Finca Santa Rosalía. Here a Valencia orchard completely recovered from a severe attack of leprosis after a management combining intense pruning and application of chemical acaricide were made, following instructions made by INTA. However, in a small plot of sweet orange cv. 'New Hall', leprosis was still present (Figure 3E). Monte Caseros is the southmost region of this province (Figure 2D, point 6), where two orchards of sweet orange were visited. One was leprosis-free, after proper management involving pruning and acaricide spraying. In the other, there was a focus which was already spreading, with plants showing symptoms on the leaves, fruits and stems (Figure 3F). Brevipalpus mites were present in all the plants showing leprosis symptoms and collected. In the EEABV, Brevipalpus mites were also collected from mandarin 'Nova' and Rhododendron sp.

Provincia de Entre Ríos: Two private sweet orange groves at the Colonia Villa Libertad, about $10 \mathrm{Km}$ South of the city of Chajarí were assessed (Figure 2D, point 7). In the first one, mostly of 'Valencia', incidence of leprosis was widespread though of low severity. In the second one, most of 'Valencia', and to a lesser extend, cv. 'Salustiana', trees 

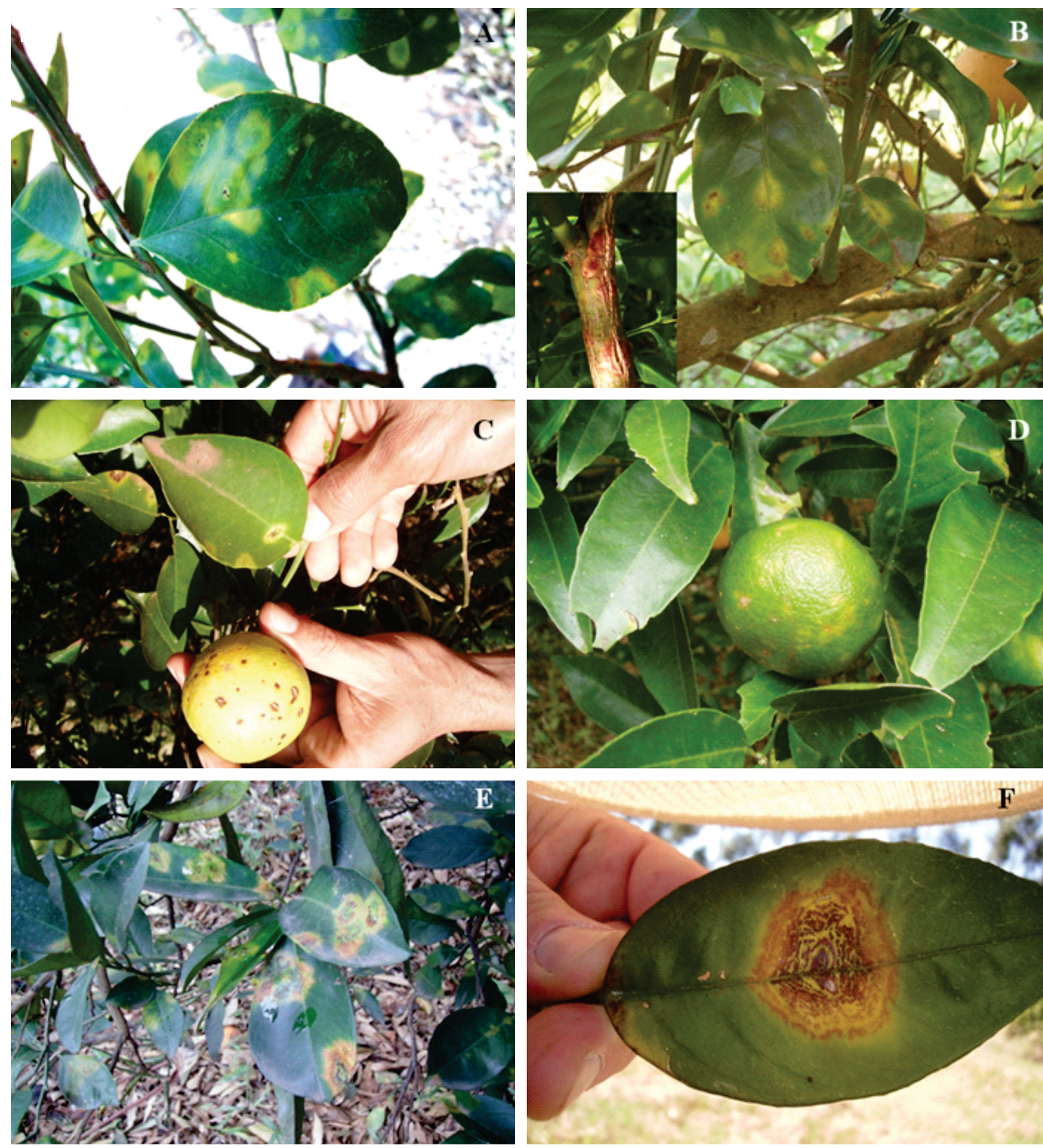

FIGURE 3 - Leaf and fruit symptoms of citrus leprosis observed during surveys made in Paraguay (A-C) and Argentina (D-F). A. Leaf symptoms in an unidentified sweet orange plant in Filadelphia (Dept. Boquerón); B. Leaf and stem (inset) lesions caused by leprosis of 'Valencia' sweet orange in the orchard of Estancia Estrella, Mbaracayú (Dept. Alto Paraná); C. Leprotic lesions on a leaf and fruit of 'Valencia' sweet orange, in the orchard of the Escuela Agrícola, Carlos Antonio López (Dept. Itapuá); D. Fruit symptoms of leprosis on 'Clemenules' mandarin, in a private orchard at Colonia Luján, Montecarlo (Prov. Misiones); E. Leprotic lesions on leaves of 'New Hall' sweet orange in a private orchard at Santa Rosa (Prov. Corrientes), F. Large leprotic lesion on a leaf of 'Valencia' sweet orange in a private orchard at Monte Caseros (Prov. Corrientes). 
were affected by leprosis. Finally, in the experimental fields of EEA Concordia (Figure 2D, point 8), leprosis was found widespread in an untreated experimental plot of seedlings of cvs. 'Común' and 'Pineapple'. Brevipalpus mites were sampled from these sweet orange plants. Although it is not possible to preclude completely the presence of the nuclear type of leprosis virus (CiLV-N), it probably does not occur in regions surveyed in this work both in Paraguay and Argentina. Characteristic leaf symptoms caused by CiLV-N (small lesions with bright yellow halos) were not observed. Short rodlike particles and the nuclear viroplasm, typical cytopathic effect of infection by CiLV-N, were not present in none of the examined tissue samples.

Symptoms of leprosis on the leaves, fruits and stems found in all localities visited, both in Paraguay and Argentina in sweet oranges and mandarins, were essentially similar and characteristic of leprosis, caused by CiLV-C (Rodrigues et al., 2003; Bastianel et al., 2010).

Most of the leaf samples with leprosis symptoms collected in Paraguay and Argentina from the inspected areas were positive for CiLV-C in RT-PCR and transmission electron (TEM) and immunofluorescence (IF) microscopy diagnosis (Figures 4, 5; Table 1). RT-PCR using specific primers for a region within the movement protein gene of CiLV-C produced the bands of the expected size (344 bp) after agarose gel electrophoresis (Figure 6). Some of the amplified fragments were sequenced ('Valencia' sweet orange samples from Chajari, Argentina, GenBank access number JX163907, and from Mbaracayú, Paraguay, JX163908). They were essentially similar, respectively $99 \%$ and $98 \%$ for Paraguayan and Argentinian samples, to those of corresponding fragment of the type isolate of the CiLV-C.
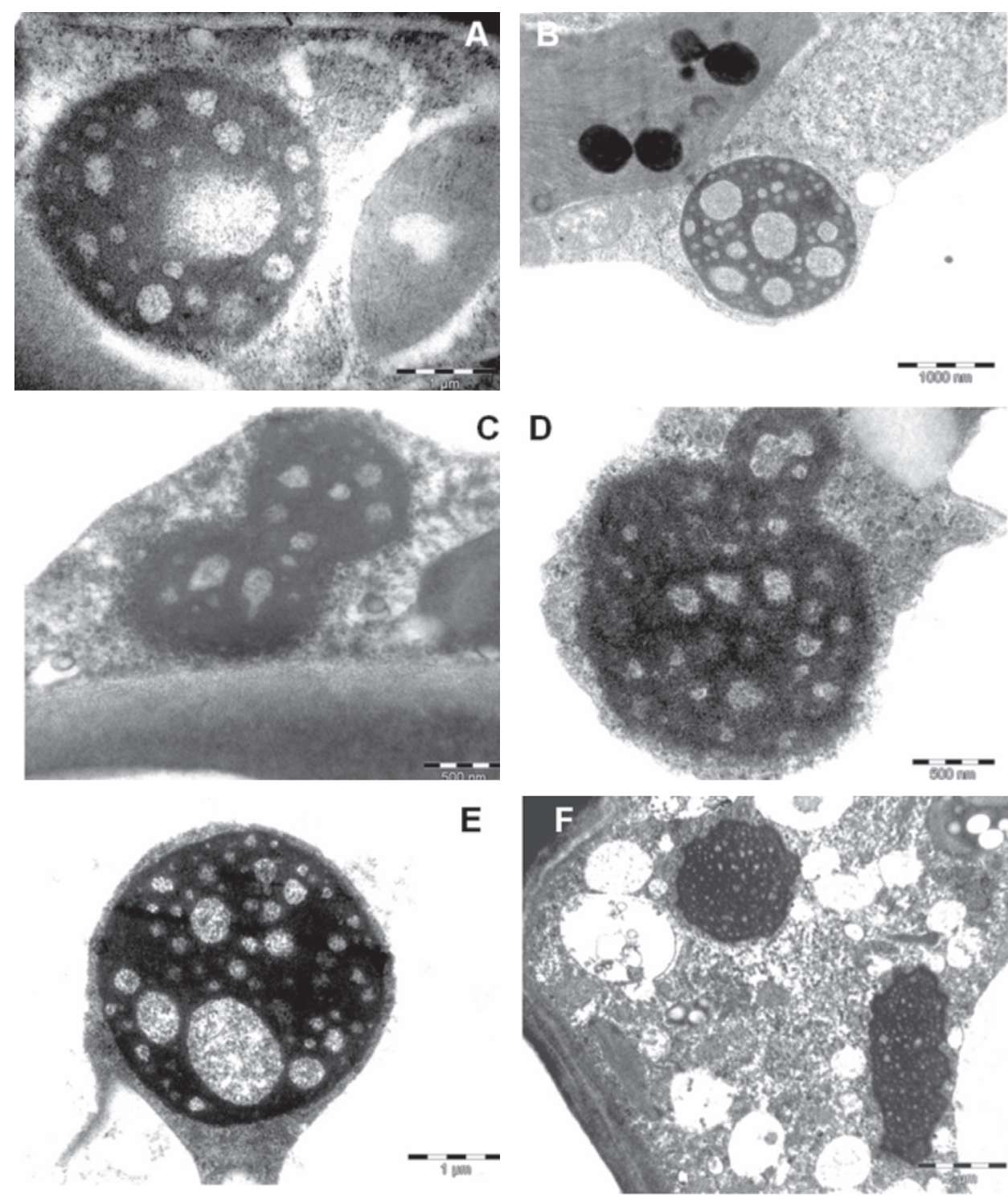

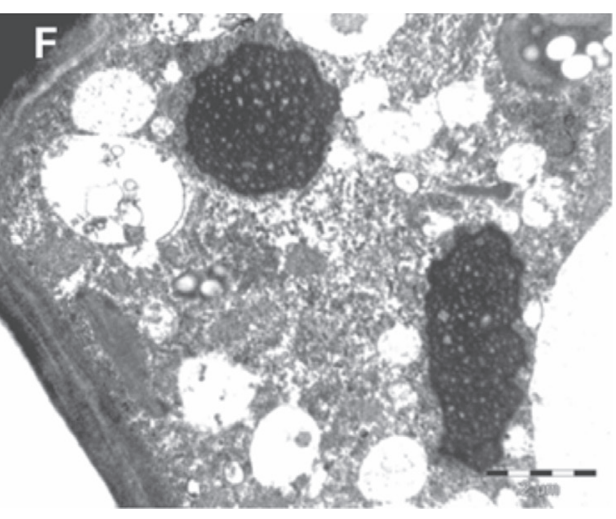

FIGURE 4 - Transmission electron micrographs of sections of leaf lesions of citrus leprosisaffected citrus plants sampled in Paraguay and Argentina, showing the characteristic electron dense and vacuolated viroplasm in the cytoplasm. A-C. Paraguay. A. 'Washington Navel' sweet orange (Experimental Station of the Cooperativa/ Filadelphia, Dept. Boquerón); B. 'Valencia' sweet orange (Instituto Agronómico Nacional, Caacupé, Dept. Cordillerras); C. 'Criolla' sweet orange (Escuela Agrícola, Carlos Antonio López, Dept. Itapuá). D-F. Argentina. D. 'Clemenules' mandarin (private orchard, Colonia Lujan, Montecarlo, prov. Misiones); E. 'Hamlin' sweet orange (Estación ExperimentalAgropecuariaBella Vista, INTA, Bella Vista, prov. Corrientes); F. 'Común' sweet orange (Estación Experimental Agropecuaria Concordia, INTA, Concordia, prov. Entre Ríos). 

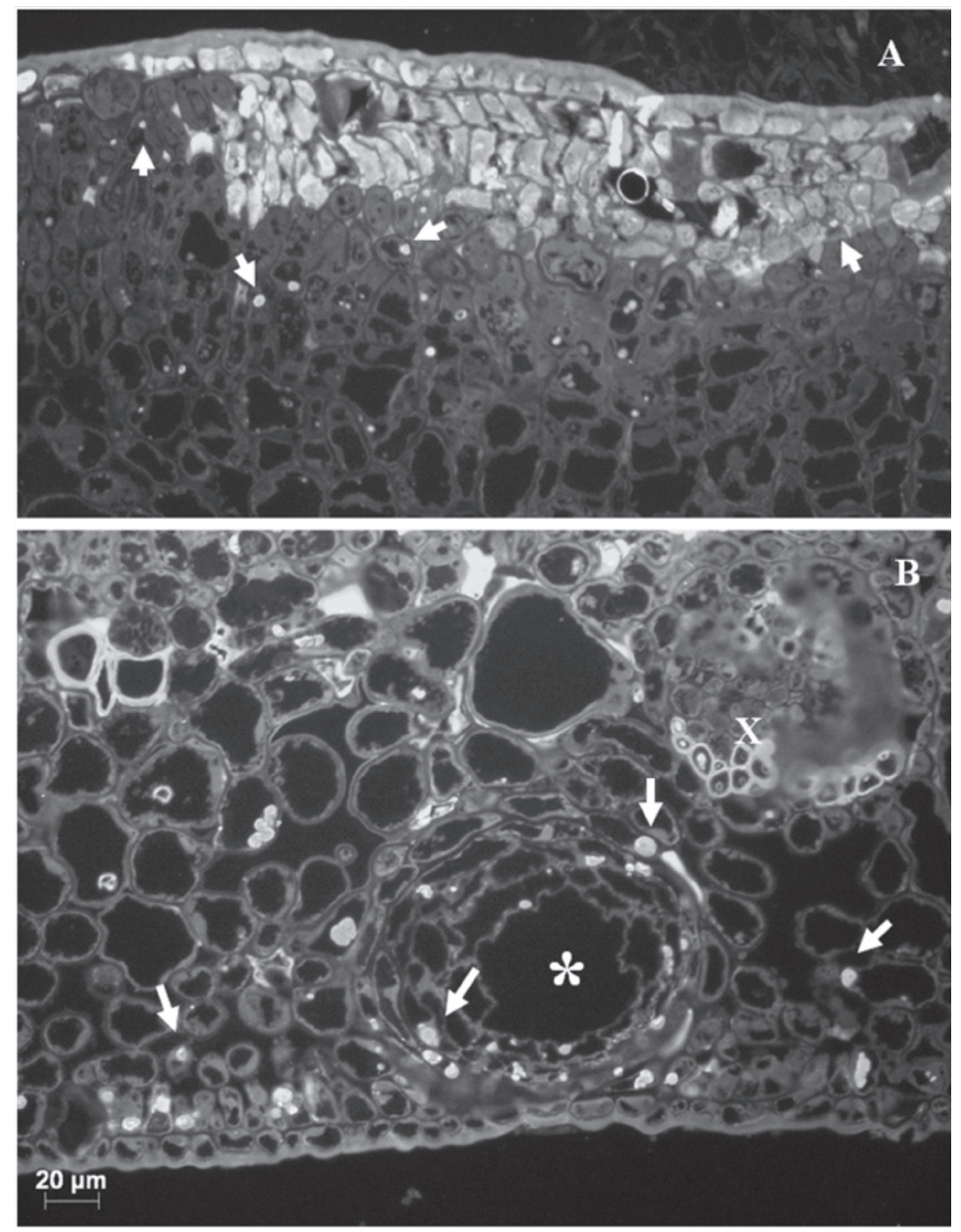

FIGURE 5 - Light micrographs of immunfluorescence assays made on leprosis affected leaf samples from Paraguay and Argentina, with antiserum against protein p29, the putative nucleocapsid protein of CiLV-C. Fluorescing viroplasmas are clearly visible (arrows) in parenchymal cells. A. 'Valencia' sweet orange from Major Otaño, Dept. Itapuá, Paraguay. Note collapsed palisade parenchyma; B. Idem, from Colonia 3 de Abril, prov. Corrientes, Argentina. *oil gland; X-xylem vessels showing autofluorescence.
In most cases, the characteristic electron dense viroplasm was observed in the cytoplasm of palisade and/or spongy parenchyma cells, and occasionally in epidermal cells, but not in the cells of the vascular bundle, as previously reported (Colariccio et al., 1995; Rodrigues et al., 2003; Bastianel et al., 2010) (Figure 4). Viral particles were rarely seen, but when present they had round to bacilliform profile and always present in cisternae of the endoplasmic reticulum. Immunofluorescence consistently detected viroplasms in the cytoplasm of either palisade or spongy parenchyma, but not in the vascular region in some selected samples from Paraguay (Filadelphia) and Argentina (Bella Vista) (Figure $5 \mathrm{~A}$ and $\mathrm{B}$ ). Most, but not all the tested samples were positive for the presence of the virus when tested by RT-PCR (Table 1 ). The negative cases were probably due to the condition of inadequate preservation of the samples. Roy et al. (2012) reported that some citrus samples from Colombia, with leprosis symptoms, were neither amplified with primers for CiLV-C nor were recognized by anti CiLV-C p29 protein antiserum. Further assays revealed that a virus structurally similar to CiLV-C was present with less than $70 \%$ nucleotide identity, which may represent a distinct virus causing symptoms similar to those by CiLV-C. This possibility may occur also in other places where plants with leprosis symptoms are present, including Paraguay and Argentina and should be considered in further surveys, especially in those which were negative for RT-PCR or immune assays. Detection of CiLV-C by TEM is known not to be reliable, because the distribution of virions or viroplasm is uneven in mature lesions, even in RT-PCR positive samples (Locali et al., 2003). This may explain the negative cases for detection of characteristic cytopathic effect of CiLV-C. However, in several of these negative cases, hypertrophy of some spongy parenchyma cells, a characteristic alteration in the lesions caused by CiLV-C (Marques et al., 2007) was evident and may be considered an indication for their infection by CiLV-C. In this sense, immunfluorescence (Figure 5) was superior to detect viroplasms, since it explores a larger area of thicker sections, which improves significantly the chances of detecting CiLV-C infected cells. All the mites 


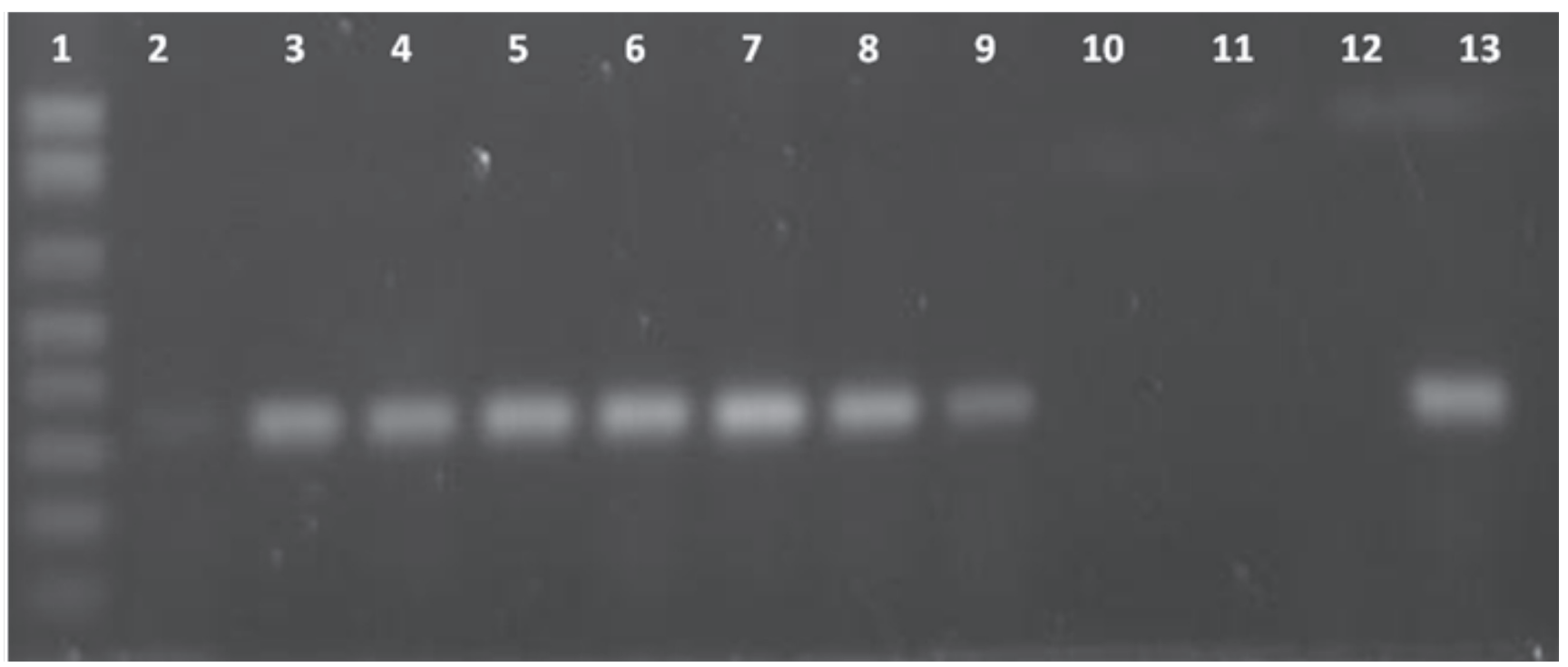

FIGURE 6 - A sample of agarose gel electrophoresis profile of RT-PCR products using specific primers (MP) for CiLV-C detection in leaf samples from sweet oranges with leprosis symptoms obtained in Paraguay. Lanes: 1- 1 kb extension ladder (Invitrogen). 2. 'Valencia' (Caacupé). 3. Unknown cv. (Esc. Agricola, Carlos Antonio López). 4. 'Valencia' (Estancia Estrella, Mbaracuyá). 5. 'Salustiana' (Estancia Estrella, Mbaracayú). 6. 'Valencia' (Esc. Agricola, Carlos Antonio López). 7. 'Valencia (Esc. Agricola, Carlos Antonio López). 8. 'Folha murcha' (Estancia Estrella, Mbaracayú). 9. . 'Valencia' (Frutika, Kressburgo). 10 and 11. Water. 12. Negative control. 13. Positive control.

collected in Paraguay (Dept. Boquerón, Dept. Itapúa) were identified as belonging to the species $B$. phoenicis based on the number of dorso-lateral setae and solenidia on the tarsus of the second leg (Welbourn et al., 2003). Those collected at Provincia de Misiones in Argentina, were also B. phoenicis. However, mites collected from sweet orange with leprosis symptoms in the Province of Corrientes and at Concordia were a mixture of $B$. phoenicis and B. obovatus and a third type, coined "asymmetric", because the number of solenidia on the tarsus of the second leg was one in one leg and two in the other (Kitajima et al., 2011b). It should be stressed that so far B. phoenicis has been the mite vector present in most of the sites where leprosis occurs throughout the Americas (Bastinael et al., 2010) as originally found in Brazil by Musumeci \& Rossetti (1963). The first description of Brevipalpus associated with leprosis was made in Argentina, by Frezzi (1940) and Vergani (1945), respectively in Bella Vista and Concordia, and the species was then identified as $B$. obovatus. Thus, there was a special interest in identifying the Brevipalpus species present in plants affected by leprosis in these sites to verify if this remained as the only species vectoring leprosis presently. Attention was given to the solenidia of the tarsus of the second leg because it serves to differentiate $B$. phoenicis and $B$. obovatus. The former has two solenidia, while the latter, only one, both having five dorsolateral setae in the opistosome (Wellbourn et al., 2003). The significance of this asymmetric type is still unknown and this finding is reported in detail elsewhere (Kitajima et al., 2011b). Apparently the mixture of the types occurred only on sweet orange with leprosis symptoms. Mites collected at EEABV on 'Nova' mandarin and Rhododendron sp., located less than $100 \mathrm{~m}$ from leprotic sweet oranges, were B. phoenicis. Thus the identity of the vector of CiLV-C in Bella Vista and Concordia is not clear yet. Further studies, analyzing isolines of these mites collected from sweet orange at EEABV is in course to understand this "asymmetry" and also to verify if only one or all the three types transmit CiLV-C. Recent works using an integrative approach, combining morphological, molecular and behavioral information (Navia et al., 2013) may help explain this peculiar situation

The survey confirmed that leprosis is endemic both in Paraguay and Argentina, but presently due to the relatively small size of the orange groves, and the actions taken by some growers, the disease is not causing severe losses. However, the foci exist and may represent a threat to future attempts at scaling up sweet orange, grapefruit or mandarin cultivation. The TEM and RT-PCR assays clearly indicated that $\mathrm{CiLV}-\mathrm{C}$ is the dominant virus causing leprosis in Paraguay and Argentina, although possible presences of CiLV-C like, but distinct virus (Roy et al., 2013) and CiLV-N cannot be precluded, as it was recently found in Querétaro, Mexico (Gabriel Otero-Colina, personal communication).

\section{ACKNOWLEDGMENTS}

This work received financial support from Fapesp (2008/52961-9). Thanks are also extended for those who helped the authors in surveys in Paraguay: Enrique Galarza (Frutika), Sergio Legal (Escuela Agrícola, Carlos Antonio 
López), Torsten Durksen e Helmut Kaethlerm (Cooperativa Colonizadora Multiactiva Fernheim), Osmar Arias and María Ramírez (Facultad de Ciencias Agrarias, UNA), Pedro Juan Caballero (Instituto Agronómico Nacional), Isácio López (Estancia Estrella), Cesar Gaut (Escuela Agrícola/ Aldea SOS, Belen, Concepción), Juan Mangelos (Escuela Agrícola Concepción). As for the surveys in Argentina, the following colleagues are thanked for that support: Noriyuki Yamada, Tomás Haberle and Jorge Krausemann (EEA Montecarlo), Oscar Rafael Benítez (Cooperativa de Tabaco de Misiones), Andrés Ramírez (EEA Bella Vista, INTA, Corrientes), Roque Dallacamina and Sebastian Perini (AER Chajarí, INTA, Entre Ríos). Cesar Martins Chagas (formerly at the Instituto Biológico de São Paulo, Brazil).

\section{REFERENCES}

Bastianel M, Freitas-Astúa J, Nicolini F, Segatti N, Novelli V, Rodrigues V, Medina CL, Machado MA (2008) Response of mandarin cultivars and hybrids to citrus leprosis virus. Journal of Plant Pathology 90:305-310.

Bastianel M, Novelli VM, Kitajima EW, Kubo KS, Bassanezi RB, Machado MA, Freitas-Astúa J (2010) Citrus leprosis: Centennial of an unusual mite virus pathosystem. Plant Disease 94:284-292.

Bitancourt AA (1934) As manchas das laranjas. Descrição das principais manchas, podridões e outras alterações das laranjas, e dos meios para combatê-las. Instituto Biológico de São Paulo, Folheto no. 53.

Bitancourt AA (1955) Estudos sobre a leprose dos Citros. I. Distribuição geográfica e sintomatologia. II. Transmissão natural às folhas. III. Transmissão natural às frutas. IV. Experiências de tratamento. Arquivos do Instituto Biológico 22:161-231.

Cáceres S, Aguirre A (2009) Manejo de la leprosis a traves del control de los vectores e impacto económico en Argentina. International Workshop on citrus quarantine pests. Villahermosa Tabasco, Mexico. Available at: www.calcitrusquality.org/wpcontent/upload/2009/05/cicaceresleprosis-en-argentinatrabajocompleto.pdf. Accessed on February 10, 2012.

Calegario RF, Locali EC, Stach-Machado DR, Peroni LA, Caserta R, Salaroli RB, Freitas-Astúa J, Machado MA, Kitajima EW (2013) Polyclonal antibodies to the putative coat protein of Citrus leprosis virus $C$ expressed in Escherichia coli: Production and use in immunodiagnosis. Tropical Plant Pathology 38:188-197.

Childers CC, Rodrigues JCV, Derrick KS, Achor DS, French JV, Welbourn WC, Ochoa R, Kitajima EW (2003) Citrus leprosis and its status in Florida and Texas: past and present. Experimental and Applied Acarology 30:181-202.

Colariccio A, Lovisolo O, Chagas CM, Galletti SR, Rossetti V, Kitajima EW (1995) Mechanical transmission and ultrastructural aspects of citrus leprosis disease. Fitopatologia Brasileira 20:208213.

Dominguez FS, Bernal A, Chiders C, Kitajima EW (2001) First report of Citrus leprosis virus in Panama. Plant Disease 85:228.

Fawcett HS (1911) Scaly bark or nail head rust of citrus. Florida Agricultural Experimental Station Bulletin 106:1-41.

Fawcett HS (1937) Contacts with Citrus industry and other observations in South America. California Citrograph 22:552575.

Fawcett HS, Bitancourt AA (1940) Observações sobre as doenças de citrus no Paraguay. Biológico 6:289-296.

Federcitrus (2011) The Argentine Citrus Industry. Available at: www.fedeercitrus.org/actividad-citricola-2011.pdf. Accessed on February 10, 2012.

Frezzi MS (1940) La lepra explosiva del naranjo - Investigaciones realizadas por el laboratorio de patología de Bella Vista (Corrientes). Boletín Frutas y Hortalizas no. 5. Buenos Aires Argentina. Ministerio de la Agricultura.

García MA (1996) Plantación y manejo de la quinta. In: Haro O (Ed.) Manual de producción de limón. Serie A n². Tucumán Argentina. INTA. pp. 113-190.

Garita-Salazar LC, Tassi AD, Kitajima EW (2011) Further progress on the use of the common bean (Phaseolus vulgaris) as an indicator plant for the Citrus leprosis virus cytoplasmic type (CiLV-C), and new experimental hosts. Virus Reviews and Research 16(Suppl.):287.

Gonzáles-Segnana LR, Villalba NV, Armadans A, Shohara K, Timmer LW (1997) Incidence of citrus tristeza and other citrus diseases in Paraguay. Proceedings of the Florida State Horticultural Society 110:43-46.

Groot TVM, Freitas-Astúa J, Kitajima EW (2006) Brevipalpus phoenicis transmits citrus leprosis virus, cytoplasmic type (CiLV-C) to common bean (Phaseolus vulgaris) under experimental conditions. Virus Review and Research 11(Suppl.):67-68.

Izquierdo-Castillo I, Zermeño-Diaz LF, Méndez W, Otero-Colina G, Freitas-Astúa J, Locali-Fabris EC, Moraes GJ, Calegario RF, Tassi AD, Kitajima EW (2011) Confirmation of the presence of the Citrus leprosis virus C (CiLV-C) in Southern Mexico. Tropical Plant Pathology 36:395-398.

Kikkert M, van Poelwijk F, Storms M, Kassies W, Bloksma H, van Lent J, Kormelink R, Goldbach R (1997) A protoplast system for studying tomato spotted wilt virus infection. Journal of General Virology 78:1755-1763.

Kitajima EW, Muller GW, Costa AS, Yuki VA (1972) Short rodlike particles associated with citrus leprosis. Virology 50:254-258.

Kitajima EW, Chagas CM, Rodrigues JCV (2003) Brevipalpustransmitted plant virus and virus-like diseases: cytopathology and some recent cases. Experimental and Applied Acarology 30:135160 .

Kitajima EW, Calegario RF, Locali-Fabris EC, Novelli VM, Bastianel M, Freitas-Astúa J, Francischini FJB (2008) In situ detection of CiLV-C in the mite vector Brevipalpus phoenicis, evidence for a circulative type of virus/vector relationship and a model for the virus circulation in the mite. Tropical Plant Pathology 33:233.

Kitajima EW, Chagas CM, Harakava R, Calegario RF, Freitas-Astúa J, Rodrigues JCV, Childers CC (2011a) Citrus leprosis in Florida, US, appears to have been caused by the nuclear type of the Citrus leprosis virus (CiLV-N). Virus Review and Research 16. Available at: www. virusreviewsandresearch.com/ISSUE16_1-2.html

Kitajima EW, Tassi AD, Novelli VM, Cáceres S, Aguirre A, Costa N, Moraes GJ (2011b) Asymmetry in the number of solenidia on the tarsus II of Brevipalpus (Acari:Tenuipalpidae) populations from Argentina. Zoosymposia 6:39-44. 
Knorr LC (1968) Studies on the etiology of leprosis in Citrus. In: Childs JFL (Ed.) Proceedings of the $4^{\text {th }}$ Conference of the International Organization of Citrus Virologists. Gainesville FL, USA. University of Florida Press. pp. 332-341.

Knorr L, DuCharme EP (1951) The relationship between the Argentina's lepra explosiva and Florida's scaly bark, with implication for the Florida citrus grower. Plant Disease Reporter 35:70-75.

Kondo H, Maeda T, Shirako Y, Tamada T (2006) Orchid fleck virus is a rhabdovirus with an unusual bipartite genome. Journal of General Virology 87:2413-2421.

Kubo KS, Arena GD, Kitajima EW, Machado MA Freitas-Astúa J (2010) Transmission of Citrus leprosis virus $C$ (CiLV-C) to Arabidopsis thaliana by Brevipalus phoenicis mites. Citrus Research \& Technology 31:85.

León MG, Becerra CH, Freitas-Astúa J, Salaroli RB, Kitajima EW (2008) Natural infection of Swinglea glutinosa by the Citrus leprosis virus, cytoplasmic type (CiLV-C) in Colombia. Plant Disease 92:1364.

Locali EC, Freitas-Astúa J, Souza AA, Takita MA, Astúa-Monge G, Antonioli R, Kitajima EW, Machado MA (2003) Development of a molecular tool for the diagnosis of leprosis, a major threat to citrus production in the Americas. Plant Disease 87:1317-1321.

Locali-Fabris EC, Freitas-Astúa J, Machado MA (2012) Genus Cilevirus. In: King AMQ, Adams MJ, Carstens EB, Lefkowitz EJ (Eds.) Virus taxonomy: classification and nomenclature of viruses: Ninth Report of the International Committee on Taxonomy of Viruses. San Diego CA, USA. Elsevier. pp. 1139-1142.

Locali-Fabris E, Freitas-Astúa J, Souza AA, Takita MA, Astúa-Monge G, Antonioli-Luizon R, Rodrigues V, Targon MLPN, Machado MA (2006) Complete nucleotide sequence, genomic organization and phylogenetic analysis of Citrus leprosis virus cytoplasmic type. Journal of General Virology 87:2721-2729.

Marchionatto JB (1950) Identificación de la lepra explosiva del naranjo con la leprosis de los citrus. Ciencia y Investigación 6:331333.

Marques JPR, Freitas-Astúa J, Kitajima EW, Apezzatto-da-Glória B (2007) Lesões foliares e de ramos de laranjeira-doce causadas pela leprose-dos-citros. Pesquisa Agropecuária Brasileira 42:1531-1536.

Maunsbach AV, Afzelius B (1999) Biomedical electron microscopy. Illustrated methods and interpretations. San Diego CA, USA. Academic Press.

Musumeci MR, Rossetti V (1963) Transmissão de sintomas de leprose dos citros pelo ácaro Brevipalpus phoenicis. Ciência e Cultura 15:228.

Navia D, Mendonça RS, Ferragut F, Miranda LC, Trincado RC, Michaux J, Navajas M (2013) Cryptic diversity in Brevipalpus mites (Tenuipalpidae). Zoologica Scripta doi:10.1111/zsc.1201
Nunes MA, Bergamini MP, Coerini LF, Bastianel M, Novelli VM, Kitajima EW, Freitas-Astúa J (2012a) Citrus leprosis virus $C$ (CiLV-C) naturally infecting Commelina benghalensis, a prevalent monocot weed of citrus orchards. Plant Disease 96:972.

Nunes MA, Oliveira CAL, Oliveira ML, Kitajima EW, Hilf ME, Gottwald TR, Freitas-Astúa J (2012b) Transmission of Citrus leprosis virus $C$ by Brevipalpus phoenicis (Geijskes) to alternate host plants found in citrus orchards. Plant Disease 96:968-972.

Pascon RC., Kitajima JP, Breton MC, Assumpção L, Greggio C, Zanca AS, Okura VK, Alegria MC, Camargo ME, Silva GGC, Cardozo JC, Vallin MA, Franco SF, Silva VH, Jordão Jr. H, Oliveira F, Giachetto PF, Ferrari F, Aguilar-Vildoso CI, Franchiscini FJB, Silva JMF, Arruda P, Ferro JA, Reinach F, Silva ACR (2006) The complete nucleotide sequence and genomic organization of Citrus leprosis associated virus, cytoplasmic type (CiLV-C). Virus Genes 32:289-298.

Rodrigues JCV, Kitajima EW, Childers CC, Chagas CM (2003) Citrus leprosis virus vectored by Brevipalpus phoenicis (Acari: Tenuipalpidae) on citrus in Brazil. Experimental and Applied Acarology 30:161-179.

Roy A, Choudhury N, León GA, Achor D, Shao J, Wei G, Picton DD, Nakhla MK, Hartaaung JS, Brlansky RH (2012) Identification of a new citrus cytoplasmic virus associated with citrus leprosis disease in Colombia using deep sequencing. Phytopathology 103(Suppl.):S4.

Sánchez-Anguiano H (2005) NAPPO Phytosanitary Alert System Availabe at: www.pestalert.org/notifications. cfm?region=Mexico. Accessed on July 9, 2005.

Spegazzini C (1920) Sobre algunas enfermedades y hongos que afectan plantas de "agrios" en el Paraguay. Annales de la Sociedad Científica Argentina 90:155-188.

Tassi AD, Freitas-Astúa J, Jadão A, Kitajima EW (2009) Citrus leprosis virus (CiLV-C)/vector relationship assessed by bean as test plant. Virus Review and Research 14 (suppl):90.

Vaccaro N, Mousqués J (1996) Plagas y su control. In: Fabiani A, Mika R, Larocca L, Anderson C (Eds) Manual para productores de naranja y mandarinas. Buenos Aires Argentina. PRODIP-INTA. pp. 131-155.

Vergani AR (1945) Transmisión y naturaleza de la "lepra explosiva"del naranjo. Buenos Aires Argentina. Ministerio de la Agricultura de la Nación, Instituto de Sanidad Vegetal. Serie A.3.

Welbourn WC, Ochoa R, Kane EC, Erbe EF (2003) Morphological observations on Brevipalpus phoenicis (Acari: Tenuipalpidae) including comparisons with B. californicus and B. obovatus. Experimental and Applied Acarolology 30:107-133.

Zeman V (1932) Lepra explosiva del naranjo. Universidad Nacional del Litoral. Facultad de Agronomía, Ganadería y Industrias afines. Corrientes Argentina. 